commercial reactor fuel. A total of $\$ 500$ million was set aside to help with the dismantling of Russian warheads, and a commercial price was fixed for the enriched uranium. Calamity appeared to have been averted.

But now this imaginative deal may be falling apart. A first shipment of uranium is due soon, but reluctantly; the Russian government is apparently having second thoughts about the price at which its enriched uranium will be sold. Part of the explanation it that the customer in the United States is not the US government, but a corporation created (and still owned) by the government with the solid-sounding name of the US Enrichment Corporation. The plan is that the company will manage not only the conversion of the Russian weapons-grade uranium into commercial fuel, but will also take over from the US Department of Energy and operate the enrichment facilities in the United States that, for half a century, have produced enriched uranium for US bombs. Eventually, the enrichment corporation will be sold into the private sector.

The US government seems to have been surprised by one consequence of this state of affairs: the enrichment company, being a commercial entity, is naturally subject to US laws on commercial trade. In particular, domestic producers of uranium are free to seek redress from the US Department of Commerce if they believe uranium is being dumped on the US market at too low a price. This is precisely what the US uranium-mining industry did in 1992, since when the Russian deal has been caught up in the bureaucracy applicable to classical trade disputes. It seems not to matter much to anybody that uranium mining in the United States is no longer a booming activity, but an industry employing just a few hundred people. A further difficulty is that the cost to the enrichment company of enriching uranium at domestic plants (which have been transferred to it at negligible cost) is less than it will have to pay for the Russian material. The result is that where once, just four years ago, there was a willing buyer and a willing seller, now both parties to the deal on Russian enriched fuel appear to have become reluctant participants.

For the past two decades, the United States has been stalwart in seeking to prevent the spread of nuclear weapons. It may have been over-zealous in seeking to prevent the extraction of plutonium from spent reactor fuel, but generally its influence has been enlightened and powerful. Who can guess where along the road to nuclear power Iraq and North Korea would now have been had it not been for US intervention? The United States has also faced down military opinions that weapons-testing should continue for the sake of winning agreement to a comprehensive ban on nuclear tests some time next year. (If only France and China would follow suit!) Yet the deal on ex-Soviet bomb-making material is potentially a more tangible contribution to the anti-proliferation cause than any other, and is in difficulties for largely administrative reasons. The US administration has other things on its mind, to be sure, but the opportunity to buy up the world's largest stock of enriched uranium deserves more attention than it has been given. And quickly.

\section{How to police fraud}

Only academic institutions can effectively impose sanctions on those found guilty of scientific misconduct.

REACTION in Britain to the serious case of scientific misconduct at St George's Hospital is in danger of getting out of hand (see Nature 375, $522 \&$ 529; 1995). Not that the facts are in dispute. A published report of the transplantation of an ectopic pregnancy into the uterus where it properly belonged was found untrue, and the surgeon primarily responsible for the publication was reported to the professional licensing authority (the General Medical Council, or GMC) and has now lost his licence to practice (but is appealing against the decision). On the face of things, St George's Hospital acted promptly and properly in dealing with the trouble, although it would have been better advised to make public the names of those appointed to carry out its internal investigation. But now the Royal College of Physicians in London plans a consultation with similar organizations on whether there should be a central body to coordinate investigations into allegations of scientific fraud.

Nothing in what follows should be construed as a suggestion that fraud in science is anything but an abomination, a means by which the mutual trust of colleagues is corroded and the literature corrupted. Nor is it in question that sanctions of some kind should be applied to those found guilty of misconduct. The practical difficulty is that only people's employers are in a position to impose sanctions on transgressors. So much should by now be clear from experience in the United States. The elaborate procedures by which the National Institutes of Health (NIH) and their sponsoring department look into allegations of misconduct yield, when successful, a mouse of a sanction. Those found guilty may be barred from applying for research grants for a certain period; they cannot be dismissed from their jobs, because they are not employed by the NIH.

In Britain, a "central body" would be a toothless animal unless it were established by statute. But what would the legal draughtsmen make of the concepts of "scientific misconduct" and of "scientist"? And how could the research community live comfortably with the results of any definitions, which would certainly be over-sharp and probably an infringement of freedom in research as well?

That is why the best that the physicians can hope for is a central body that does not have investigatory powers and sanctions of its own, but which can function as a means of keeping academic institutions up to scratch. As things are, institutions have more to gain from sweeping scandal under the rug of public ignorance than from the thorough investigation of accusations of misconduct. What is needed is a mechanism for compelling institutions to face up to their responsibilities on fraud. A central body that did no more than publish once a year a list of all investigations into misconduct by institutions in its purview, and which commented on their adequacy, would be a public service. But that is probably the most that can be done. 